J. Dairy Sci. 94:1641-1641

doi:10.3168/jds.2011-94-3-1641

(c) American Dairy Science Association ${ }^{\circledR}, 2011$.

\title{
Erratum to "Direct-fed microbial supplementation on ruminal digestion, health, and performance of pre- and postpartum dairy cattle" (J. Dairy Sci. 89:260-266)
}

\section{J. E. Nocek and W. P. Kautz}

In several locations in the paper, the direct-fed microbial supplement was incorrectly described with respect to the number of viable yeast cells: in the abstract (page 260), in the first paragraph of Materials and Methods (page 261), in the footnotes to Tables 1 through 7, and in the captions of Figures 1 to 3. The correct description is as follows: The direct-fed microbial (DFM) supplement was fed at a rate of $\mathbf{2} \times \mathbf{1 0}^{\mathbf{9}}$ viable yeast cells and $5 \times$ $10^{9} \mathrm{cfu}$ of bacteria per cow per day.

In the Materials and Methods section (page 261), the fourth sentence of the first paragraph should read "The treatments were control (prepartum and postpartum TMR with no DFM supplementation) or DFM [control prepartum and postpartum TMR with inclusion of $2 \mathrm{~g}$ of DFM/cow per d (Probios TC, Chr. Hansen, Milwaukee, WI; the DFM contained $2 \times 10^{9}$ viable yeast cells and $5 \times 10^{9}$ cfu of bacteria)]."

The authors regret the error.

Nocek, J. E., and W. P. Kautz. 2006. Direct-fed microbial supplementation on ruminal digestion, health, and performance of pre- and postpartum dairy cattle. J. Dairy Sci. 89(1):260-266. 